УДК 656.2.001.47

\title{
ОСОБЛИВОСТІ ФОРМУВАННЯ КОРПОРАТИВНОЇ КУЛЬТУРИ ОРГАНІЗАЦІї
}

\author{
Гриценко Н.В., к.е.н., доцент (УкрДУЗТ)
}

В даній статті досліджено теоретичні аспекти формування сучасних стосунків $i$ аргументовано нові підходи до формування культури. Корпоративна культура складається не відразу, прочес ї̈ формування складний і тривалий у часі. Він розвивається за своїми специффічними законами, має свої принципи, та передбачає певні етапи. Крім інструментів інформаційного впливу на працівників, в організачії повинні бути вироблена певна внутрішня організаційна політика, яка буде підтримувати декларачї щуодо тих або інших цінностей. Проаналізовано етапи удосконалення корпоративної культури в організації, та встановлено, щзо, для успішного формування культури організації $i$ зниження опору персоналу бажано створити систему мотивачії реалізації програми формування $i$ розвитку корпоративної культури для працівників кожного рівня. Доведено, щзо для зниження опору працівників необхідно розробити таку програму нововведень, яка б була зрозуміла кожному працівнику. Всі нововведення повинні заздалегідь обговорюватися на нарадах, а найкардинальніші зміни на загальних зборах. При формуванні і розвитку корпоративної культури важливо враховувати думки прачівників. При запуску програми повинен працюювати так званий принцип «першого керівника»: керівник організачії власним прикладом повинен підтверджувати необхідність і правильність здійснюваних змін і нововведень. Особливо ие важливо для організачій, в яких завжди периа особа в організації користується великим авторитетом серед працівників. Всі рівні повинні бути залучені до прочесу формування і розвитку корпоративної культури. Якщо на якомусь з рівнів нововведення не приймаються, викликають опір, їх необхідно корегувати знову на самому вищому рівні. Доведено, щуо формування корпоративної культури, у сучасних умовах функціонування, є глобальним стратегічним ресурсом організаиіï.

Ключові слова: корпоративна культура, організація, персонал, керівництво.

\section{ОСОБЕННОСТИ ФОРМИРОВАНИЯ КОРПОРАТИВНОЙ КУЛЬТУРЫ ОРГАНИЗАЦИИ}

\author{
Гриценко Н.В., к.э.н., доцент (УкрГУЖТ)
}

В данной статье исследованы теоретические аспекты по формированию современных отномений и аргументированы новые подходы $\kappa$ формированию культуры. Корпоративная культура складывается не сразу, прочесс ее формирования сложный и длительный во времени. Он развивается по своим специфическим законам, имеет свои принципы, и предусматривает определенные этапы. Кроме инструментов информаџионного воздействия на работников, в организаџии должна быть выработана определенная внутренняя организационная политика, которая будет поддерживать деклараџии по тем или иным цееностям. Проанализированы этапьы 
совершенствования корпоративной культуры в организации, и установлено, что для успешного формирования культуры организации и снижение сопротивления персонала желательно создать систему мотивации реализаџии программы формирования и развития корпоративной культуры для работников каждого уровня. Доказано, что для снижения сопротивления работников необходимо разработать такую программу нововведений, которая была понятна каждому работнику. Все нововведения должны заранее обсуждаться на совещаниях, а кардинальные изменения на общем собрании. При формировании и развитии корпоративной культуры важно учитывать мнение работников. При запуске программы должен работать так называемыий принцип «nервого руководителя»: руководитель организации своим примером должен подтверждать необходимость и правильность осуществляемых изменений $u$ нововведений. Особенно это важно для организаций, в которых всегда первое лицо в организачии пользуется большим авторитетом среди работников. Все уровни должни быть вовлечены в прочесс формирования и развития корпоративной культуры. Если на каком-то из уровней нововведения не принимаются, вызывают сопротивление, их необходимо корректировать вновь на самом высшем уровне. Доказано, что формирование корпоративной культуры в современных условиях функционирования, является глобальным стратегическим ресурсом организации.

Ключевые слова: корпоративная культура, организация, персонал, руководство.

\section{PECULIARITIES OF CORPORATE CULTURE OF THE ORGANIZATION}

\section{Gritsenko N.V., Candidate of Economic Sciences, Associate Professor (USURT)}

In this article, theoretical aspects of the formation of modern relations are explored and new approaches to the formation of culture are argued. Corporate culture is not formed immediately, the process of its formation is complex and time-consuming. It develops according to its specific laws, has its own principles, and provides for certain stages. In addition to the tools of information impact on employees, the organization should develop a certain internal organizational policy that will support declarations on these or other values. The stages of improving the corporate culture in the organization were analyzed and it was found that for the successful formation of the culture of organization and the reduction of staff resistance it is desirable to create a system for motivating the implementation of the program for the formation and development of a corporate culture for workers at each level. It is proved that to reduce the resistance of workers it is necessary to develop a program of innovations that was understandable to every employee. All innovations should be discussed in advance at meetings, and cardinal changes at the general meeting. When forming and developing a corporate culture, it is important to take into account the opinion of employees. When starting the program, the so-called "first manager" principle should work: the head of the organization, by his example, must confirm the necessity and correctness of the changes and innovations that are being implemented. This is especially important for organizations in which the first person in the organization always enjoys great authority among employees. All levels must be involved in the process of formation and development of corporate culture. If at some level of innovation is not accepted, cause resistance, they must be adjusted again at the highest level. It is proved that the formation of a corporate culture in the current conditions of functioning is a global strategic resource of the organization.

Keywords: corporate culture, organization, personnel, leadership.

Вісник економіки транспорту і промисловості № 59, 2017 
Постановка завдання дослідження. Потенціалом будь якої організації $\epsilon$ iii корпоративна культура, в якій будуються відношення між членами колективу. Значення корпоративної культури організації в тому, що вона проявляється у формуванні цінностей і принципів, які визначаються керівництвом організації, в етичних нормах і офіціальній політиці, в традиціях організації, в міжособистих стосунках, практиці контролю за роботою працівників, у внутрішньому середовищі організації, що об'єднується поняттям культура організації. При цьому слід відмітити, що корпоративна культура не $\epsilon$ статичною, раз назавжди встановленою формою взаємовідносин в організації. В цілому корпоративна культура організації відіграє дуже важливу роль в і1і функціонуванні, тому що вона розвиває написані, часто невисловлені норми i взаємні очікування, які досить сильно впливають на поведінку колективу.

Аналіз досліджень і публікацій. Багато вчених займались даною тематикою такі як, Андрефф В., Розбард Т. [1], Башук Т. [2], Гриценко Н. [3,4,5], Тимцуник В., Бєлова О. [6], однак, питання щодо формування нових стосунків і підходів до корпоративної культури організації не розкрито зі сторони внутрішньо організаційної політики, що підтримує декларації тих або інших цінностей організації, і потребує ретельного вивчення та вдосконалення, тому метою даної статті $€$ формування гнучкої корпоративної культури організації, яка дозволить членам організації регулювати як формальні, так i неформальні відносини.

\section{Виклад основного}

матеріалу. Формування культури в організації пов'язане з впливом культури суспільства, у середині якого дана організація функціонує. Правила культури які будуть враховувати такі аспекти, як адаптація нових працівників, поведінка працівників на нарадах, міжособисті неформальні відносини, дрескод 3 одягу, зовнішне оформлення сприятимуть організації

тощо, психологічному клімату в колективі і в подальшому стануть стратегічним ресурсом організації.

При формуванні корпоративної культури організації, яка б підтримувала стратегію гнучкого організаційного розвитку, необхідно виконати ряд відповідних кроків [1,2]:

1) визначити стратегію щодо встановлення основних цілей і цінностей, бажаних пріоритетів, принципів, норм поведінки колективу;

2) виявити позитивні i негативні цінності. Визначити ступень відповідності існуючої корпоративної культури обраної керівництвом, яка впливає на стратегію розвитку організації;

3) створити організаційні заходи, спрямовані на формування бажаних цінностей і зразків поведінки;

4) здійснити гнучкий вплив на корпоративну культуру 3 метою подолання негативних аспектів, які будуть сприяти реалізації обраної стратегії;

5) оцінити успішність впливу стратегії організації на корпоративну культуру і за необхідністю, внесення корективів у дану стратегію.

Предметом

дослідження сформованого в організації культурного середовища $\epsilon$ вирішення трьох завдань: 1 - усвідомлення провідних цінностей, пріоритетів, настанов, покликаних підтримати перспективну організаційну стратегію; 2 - визначення культурних цінностей організації, що будуть сприяти реалізації цілі; 3 - аналіз існуючої корпоративної культури та оцінка розвитку організації.

На сьогоднішній день корпоративна культура відіграє важливу роль в системі управління персоналом підприємства i розглядається як стратегічний інструмент, що дозволяє орієнтувати усі його підрозділи та усіх працівників на загальні цілі, підвищувати ініціативу, забезпечувати відданість загальній справі, 
полегшувати спілкування. Більшість труднощів, які виникають в стратегічному управлінні персоналом здатний вирішити ефективний мотиваційний механізм, що має діяти на підприємстві. Корпоративна культура, як його основа, сприяє встановленню “стратегічної налаштованості” працівників, що призводить до підвищення продуктивності ïx праці та до оптимізації стратегічного управління в цілому [3].

Формування корпоративної культури організації повинно відбуватися цілеспрямовано, та бути здатним ефективно реагувати на ситуації, як відносно стабільні, так і нові, спонтанні. При цьому корпоративна культура повинна зміцнювати колективний дух працівників від низьких до вищих ланок.

Процес формування корпоративної культури знаходить свій відбиток у формуванні «обличчя» організації, що включає особливості їі діяльності, основні принципи та стиль, а також зобов'язання стосовно споживачів та персоналу. Чітко подані, сформовані, водночас гнучкі принципи i зобов'язання дозволяють формувати, об'єднувати працівників навколо єдиних, ясно визначених цілей $\mathrm{i}$ цінностей. Тобто необхідно виробити певний формалізований механізм, який повинен відповідати головним етапам формування корпоративної культури i бути здатним виконувати свою інституційну роль за будь-яких умов $[3,4]$. Даний механізм визначає домінуючи особисті цінності в колективі та ієрархію. Ієрархічна система виділених у такий спосіб цінностей породжує найбільш адекватну сукупність засобів їхньої реалізації, що втілюючись у засобах діяльності, формують внутрішньо групові норми, цінності і моделі поведінки.

Основні принципи корпоративної культури загалом можуть забезпечувати позитивний кінцевий результат внаслідок взаємодії, звичайно 3 дотриманням індивідуального підходу до кожної людини, будь-якого колективу в організації.

В корпоративній культурі виділяють два рівні корпоративної культури: зовнішній та внутрішній.

Зовнішній рівень можна поділити ще на два підрівні: усвідомлений (це об'єкти які ми бачимо), наприклад: стиль одягу, правила поведінки, певні символи, церемонії, що відбуваються в колективі (організації) і неусвідомлений (це цінності, яких ми не бачимо), наприклад: неписані правила, негласні угоди тощо.

Внутрішній рівень - цінності та переконання виражені в діяльності співробітників організації, що свідомо культивуються ними i в процесі життєдіяльності проникають в глибину корпоративної культури. Ці базові переконання являють собою сутність корпоративної культури.

Крім того, важливим чинником корпоративної культури, безумовно $\epsilon$ наявність власної культури кожного співробітника колективу (організації), що $\epsilon$ особистістю та володіє власною системою ціннісних установок, які тією або іншою мірою впливають на суспільну свідомість організації та на формування i спрямованість корпоративної культури.

В корпоративній культурі виділяють три основних компоненти [5]:

1. Базисні передумови поведінки, яких дотримуються члени організації в своїй поведінці та діях, що досить часто пов'язано 3 баченням навколишнього середовища людини (групи, організації, суспільства тощо) та регулюючих іiі змінних (природа, час, робота, характер відношень).

2. Ціннісні орієнтації - які орієнтують членів організації та визначають форму поведінки, що можливо вважати гідною, або неприйнятною. Все це залежить від домінуючих цінностей організації, та дозволяє зрозуміти як людина має діяти в певній ситуації.

3. Символіка завдяки якій передаються ціннісні орієнтації конкретної організації членам цієї ж 
організації. Вона існує у вигляді різноманітних історій, легенд та міфів, що впливають на людей.

Від успішного втілення цих компонентів загалом i залежить успіх діяльності організації, що в свою чергу, наголошує на здатності організації сформувати свою власну корпоративну культуру, своєрідний моральний клімат в колективі, що також формується корпоративною етикою.

Також, існує система особистих цінностей, переконань, традицій і норм поведінки працівників [5,6]. Вона виражається в символічних засобах духовного й матеріального оточення людей, що працюють у даній організації (рис. 1).

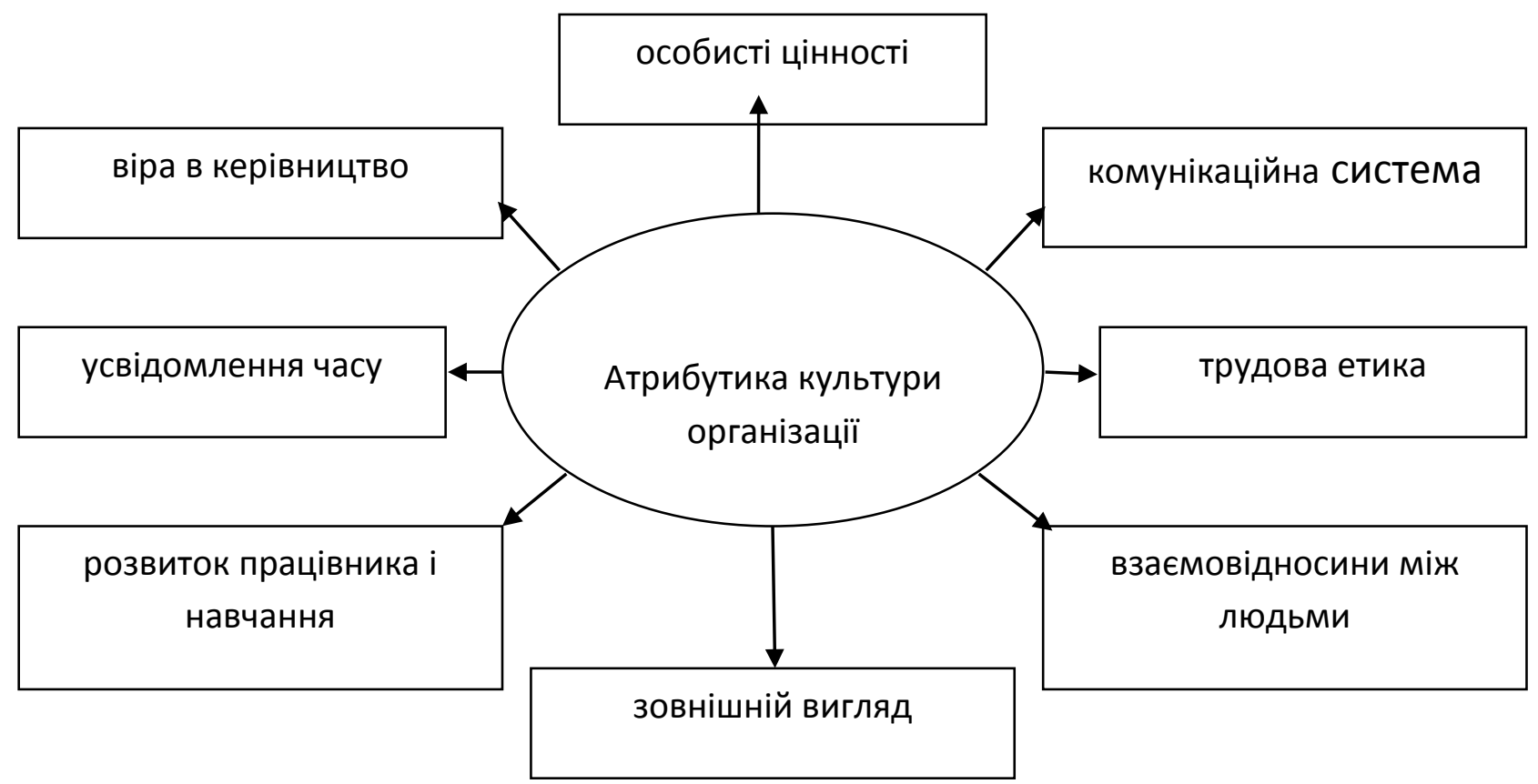

Рис. 1. Складові культури організації

Зробимо аналіз складових, що характеризують культуру організації.

- особисті цінності, тобто що люди цінують у своєму житті, в організації: своє положення, титули, просування по службі, саму роботу.

- віра в керівництво. Кожен співробітник працює 3 вірою в керівництво, в успіх, у свої сили, у взаємодопомогу, в етичну поведінку, у справедливість і т.п. Це потрібно не тільки 3 точки зору особистості, а й у досягненні загальної мети організації.

- комунікаційна система i мова спілкування, тобто використання усної, писемної, невербальної комунікації, абревіатури, жестикуляції й т.п.

- усвідомлення часу, ставлення до нього i його використання: ступінь точності часу у працівників, дотримання тимчасового розпорядку й заохочення за це.

- взаємовідносини між людьми, що розрізняються за віком і статтю, статусом й владою, досвідом й знаннями, релігією й громадянством, а також шляхи й методи вирішення виникаючих конфліктів.

- процес розвитку працівника i навчання: процедури інформування працівників, порядок участі в навчальних програмах, значення процесу підвищення кваліфікації, що використовується в організації;

трудова етика й методи стимулювання: ставлення до роботи й відповідальність за доручену справу; поділ праці й виконання посадових обов'язків; оформлення і чистота робочого 
місця; якість роботи; оцінка роботи і винагорода; шляхи просування по службі.

- зовнішній вигляд, одяг, подання себе на роботі, діловий стиль працівника.

Всі характеристики, взяті разом, формують організаційну культуру. Вони відображаються в традиціях, у поведінці людей, у їхньому зовнішньому вигляді, у манері спілкування, у їхніх діях і емоціях. Люди, що працюють в організації, формують іiі культуру, i у той же час культура впливає на поведінку людей в організації. Культура організації проявляється через уявлення про цінності, 3 них виводяться норми й правила поведінки, на основі яких, у свою чергу, формується конкретна поведінка працівників усередині й поза організацією. Поділені цінності формують у членів організації стандарти в діях і схожі почуття. Вони проявляються в матеріальних i духовних символічних речах: зовнішньому вигляді офісних приміщень, самих співробітників, у символах i фірмовому стилі, формах винагород і заохочень.

Виходячи 3 вищенаведеного, культура організації це узагальнююча характеристика всієї організації в цілому, елементами якої є:

- цінності, соціальні установки;

- моральні принципи й ділова етика;

- методи мотивації працівників;

- організація праці й способи контролю;

- стиль керівництва;

- шляхи вирішення конфліктів;

- способи прийняття рішень;

- комунікації.

Формування культури організації $є$ складним феноменом. До особливостей формування, входять такі відомі норми як: принципи, правила, цінності, ідеали, мова, жаргон, історія організації, легенди, образи, символи, метафори, церемонії, ритуали, форми винагород i заохочень, оточення. Дані особливості, як правило носять неформалізований характер, i можуть змінюватись в залежності від зовнішніх та внутрішніх факторів організації.

Однак

головною особливістю формування культури організації $\epsilon$ перетворення необхідних гнучких норм, цінностей та принципів, а також зміни реального життя в організації (тобто, деталі внутрішніх відносин між особистостями).

Висновок. Таким чином, корпоративна культура $є$ головним механізмом, що забезпечує практичне підвищення ефективності роботи організації. Ключовим фактором у формуванні корпоративної культури особливо мають цінності такі елементи як: відповідальність, чесність, здібність, самоповага, безпека сім’ї та свобода.

Формування корпоративної культури підтримує формування стратегії організації та $є$ важливим механізмом для успішного виконання іiі завдань, адже культура формує соціально-психологічний клімат i корпоративний дух, які сприяють виконанню поставлених завдань та досягненню успіху всієї організації. Корпоративна культура відбиває атмосферу в організації.

Слід зазначити, що корпоративна культура, завжди, повинна підтримувати місію, цілі та конкретну стратегію розвитку організації. При цьому мета поєднання місії i культури носить довгостроковий характер, що сприяє досягненню максимальних результатів, при цьому зміни, вироблені в корпоративній культурі потребують високого ступеня компетентності 3 боку керівництва організації.

На стан і розвиток внутрішньої культури організації значний вплив сприяє зовнішне середовище. $\mathrm{y}$ різних організаціях формується специфічна внутрішня культура, водночас культурні цінності підприємств однієї галузі нерідко збігаються, оскільки організації працюють в однакових зовнішніх умовах. Внутрішня культура повинна сприяти досягненню цілей організації. Однак зміна зовнішнього 
середовища вимагає також постійного внесення відповідних змін у внутрішню організаційну структуру підприємства. Тому важливим $є$ формування здатності адаптації корпоративної структури до змін зовнішніх умов діяльності організації.

\section{ПЕРЕЛІК ВИКОРИСТАНИХ ДЖЕРЕЛ}

1. Андрефф В. Новая корпоративная стратегия / В. Андрефф, Т. Розбард. Слб.: Питер Ком. - 2009. - 416 с.

2. Башук Т.О. Доцільність формування корпоративної культури на підприємстві / Т.О. Башук, А.М. Жолудєва // Маркетинг і менеджмент інновацій. Харків, 2011. - №2. - С. 179-184.

3. Гриценко Н.В. Перспективы альтернативного железнодорожного управления транспорта
Гриценко // «Ученые записи»-Scientifics works. - Баку, 2014. - №1 С. 129-132.

4. Гриценко Н.В. Оптимізація діяльності впливу керівника на співробітників / Н.В. Гриценко // Наук. вісн. Одеського націон. економ. університету. - Одеса, 2015.- 6(226). - С. $68-74$.

5. Гриценко Н.В. Діяльність менеджера в сфері управління людськими ресурсами / Н.В. Гриценко // Вісник економіки транспорту і промисловості. Хрків, 2016. - №54. - С. 345-349.

6. Тимцуник B.I. Корпоративна культура як основа формування мотиваційного механізму у стратегічному управлінні підприємством / В.I. Тимцуник, O.I. Бєлова // Наук. вісн. акад муніцип. управління. - Харків, 2011. - №2. - С. 5459.

\title{
УДК 330.59
}

\section{УРОВЕНЬ И КАЧЕСТВО ЖИЗНИ: ЭКОНОМИЧЕСКИЕ ОСНОВАНИЯ}

\author{
Комаренко О.А., аспирант (ХНУ им. Каразина)
}

В данной статье предпринята попытка выявить, с одной стороны, элементы соподчиненности, сопряженности, с другой, отличительные особенности, специфику категорий «уровень жизни» $u$ «качество жизни». $B$ работе определен господствующиий в сочиально-экономической литературе подход $\kappa$ пониманию сущности категории «уровень жизни» и обоснована авторская трактовка её.

На основе анализа современных изменений в подходах к содержанию понятия «благосостояние» обоснована актуальность разработки концепции качества жизни. Даются отличительные свойства категории "качество жизни», рассматриваются его структура и анализируется его объективные и субъективные показатели. Делается вывод о том, что экономическим основанием качества жизни как сочиологической категории выступает уровень жизни.

Ключевые слова: уровень жизни, качество жсизни, материальное благосостояние, условия жнизи, стоимость жизни, объективные характеристики качества энизни, субъективное восприятие благосостояния. 